\title{
Editorial
}

\section{Special Issue: Fluid Flow in Fractured Porous Media}

\author{
Richeng Liu ${ }^{1,2} \mathbb{D}$ and Yujing Jiang ${ }^{2, *}$ (1) \\ 1 State Key Laboratory for Geomechanics and Deep Underground Engineering, China University of Mining \\ and Technology, Xuzhou 221116, China; liuricheng@cumt.edu.cn \\ 2 School of Engineering, Nagasaki University, 1-14 Bunkyo-machi, Nagasaki 8528521, Japan \\ * Correspondence: jiang@nagasaki-u.ac.jp; Tel.: +81-95-819-2612
}

Received: 28 September 2018; Accepted: 28 September 2018; Published: 1 October 2018

The fluid flow in fractured porous media plays a significant role in the characteristic/assessment of deep underground reservoirs such as $\mathrm{CO}_{2}$ sequestration [1-3], enhanced oil recovery [4,5] and geothermal energy development [6,7]. Many methods, including laboratory experiments, theoretical analysis and numerical simulation, and many models including the discrete fracture network (DFN) model [8-10], the channeling network (CN) model [11-13] and the dual-porosity model [14,15], have been employed to investigate fluid flow in fractured porous media. The early studies commonly assumed that fluid flow obeys the cubic law and that fluid flow is in the linear flow regime [16-23], whereas recent studies also investigated the nonlinear flow through rock fractures/fracture networks [24-33]. However, due to the complex and uncertain geometric properties of rock masses deep underground, extensive studies on the hydraulic properties of fractured porous media and engineering applications are still needed.

Therefore, we are handling a Special Issue (SI) of Processes on fluid flow in fractured porous media (http://www.mdpi.com/journal/processes/special_issues/porous_media), which is now ongoing until the deadline of 31 December 2018. This SI has published 27 high quality papers and another 8 papers are under review. The accepted papers include a wide variety of topics such as granite permeability investigation, grouting, coal mining, roadway, concrete and so on. The details of these accepted papers in the SI are summarized individually as follows:

(1) He, L. et al., Laboratory Investigation of Granite Permeability after High-Temperature Exposure. [34]

The very first accepted paper of the Special Issue on "Fluid flow in fractured porous media" presented a series of flow tests on granite after high temperature treatment of up to $800^{\circ} \mathrm{C}$. The results showed that higher temperatures induce a larger number of micro-fractures and the larger decrement ratios of both the P-wave velocity and the density of granite. The tested equivalent permeability increases with increasing temperature, following an exponential function.

(2) Jin, Y. et al., Experimental Investigation of the Mechanical Behaviors of Grouted Sand with UF-OA Grouts. [35]

This paper investigated the effect of a newly developed grouting material - which is a chemical material-ureaformaldehyde resin mixed with oxalate curing agent (UF-OA) —on the mechanical behaviors of sand specimens through uniaxial compression tests. The results showed that the presence of initial water can decrease both the uniaxial compressive strength (UCS) and the elastic moduli (E) of the grouted specimens; however, the peak strain $\left(\varepsilon_{\mathrm{c}}\right)$ does not change significantly after 14 days of curing. 
(3) Yan, S. et al., Key Parameters of Gob-Side Entry Retaining in a Gassy and Thin Coal Seam with Hard Roof. [36]

This paper analyzed the gas concentration and air pressure in the gob and proposed a roof-cutting mechanical model of gob-side entry retaining (GER) with a roadside backfill body (RBB) to determine the key parameters of the GER-TCS. Here, TCS denotes the thin coal seam. They reported that a greater RBB width results in greater roof-cutting resistance and the floor heave of GER increases with increasing RBB width. Finally, the validity of the proposed model is verified by comparing the calculated results with in situ measurements.

(4) Li, J. et al., Effects of Water Soaked Height on the Deformation and Crushing Characteristics of Loose Gangue Backfill Material in Solid Backfill Coal Mining. [37]

This paper studied the effect of water soaked height in coal mines on the deformation and crushing characteristics of loose gangue backfill material (LGBM). They concluded that, with the increment of water socked height, both the crushing ratio and the maximum axial strain of LGBM specimens increase. The crushing ratio has a strong linear correlation with the maximum axial strain and a higher water soaked height leads to a lower deformation resistance and a more significant influence on the quality of backfilling.

(5) Liu, J. et al., Investigation on Reinforcement and Lapping Effect of Fracture Grouting in Yellow River Embankment. [38]

This paper carried out a series of laboratory and in situ experiments to characterize the reinforcement effect of fracture grouting on the Yellow River Embankment. The results showed that the optimum mixing proportion of the compound cement-silicate grout is $70 \%$ cement, $25 \%$ fly ash and $5 \%$ bentonite. The interval distance of the injection hole is suggested to be $1.2 \mathrm{~m}$, in which the lapping effect of fracture grouting veins play an import role.

(6) Ma, C. et al., Deformation and Control Countermeasure of Surrounding Rocks for Water-Dripping Roadway below a Contiguous Seam Goaf. [39]

This paper studied the deformation of rocks surrounding the roadway using numerical simulation and proposed a mechanical model of water-dripping rock using a bolt support. They found that the erosion by water that is dripped on the roadway is substantial and changes significantly over time during roadway excavation. The suggested bolt line spacing is $0.7 \sim 0.9 \mathrm{~m}$ and the suggested tightening force should exceed $40 \mathrm{kN}$.

(7) Liu, R. et al., Investigation of the Porosity Distribution, Permeability and Mechanical Performance of Pervious Concretes. [40]

This paper investigated the performance of pervious concrete, such as its porosity, pore distribution, permeability coefficient and mechanical properties, with laboratory tests. The main conclusions are that the standard deviation of permeability is less than 0.03 under different hydraulic gradients. The permeability is closely correlated with the volumetric porosity (or effective pore size $\mathrm{d}_{50}$ ), following polynomial functions.

(8) Xie, X. et al., Critical Hydraulic Gradient of Internal Erosion at the Soil-Structure Interface. [41]

This paper carried out orthogonal and single-factor tests to estimate the critical hydraulic gradient of internal erosion on soil-structure interfaces. They reported that the critical hydraulic gradient is mostly sensitive to degree of compaction, followed by roughness and clay content. The internal erosion is found to develop inside first and then extend to the outside along the interface. 
(9) Cui, Y. et al., A New Pseudo Steady-State Constant for a Vertical Well with Finite-Conductivity Fracture. [42]

The authors proposed a new semi-analytical solution for the Pseudo Steady-State constant, which is defined as the difference between the dimensionless wellbore pressure and dimensionless average pressure and is an important parameter for describing Type Curves. They derived a new conductivity-influence function and a normalized conductivity-influence function, which are then utilized to derive the approximate solute of Pseudo Steady-State constant.

(10) Li, Z. et al., The Fracturing Behavior of Tight Glutenites Subjected to Hydraulic Pressure. [43]

Numerical simulations were performed to model the fracturing behaviors of tight glutenites, in which the glutenite heterogeneity has been taken into account. The main conclusions are that the hydraulic fractures propagate along the gravels, influenced by stress anisotropy and gravel strength. When the gravel distribution orientation, size and axial ratio are considered, the fractures propagate past the gravel, forming a bypass fracture.

(11) Chen, S. et al., Experimental Study of the Microstructural Evolution of Glauberite and Its Weakening Mechanism under the Effect of Thermal-Hydrological-Chemical Coupling. [44]

This paper focuses on the microsctructure evolution of glaubeite under different leaching conditions. Cylindrical specimens with a size of $3 \mathrm{~mm}$ in diameter and $10 \mathrm{~mm}$ in length were cored from a bedded salt deposit buried at over $1000 \mathrm{~m}$ depth in Yunying salt formation, China. The results show that those specimens immersed in a solution at a low temperature generate cracks at the center of the disc. With incremental increase of the temperature of the solution, the crack nucleation appears and the dissolution rate increases significantly.

(12) Zhu, D. et al., Experimental Study on the Damage of Granite by Acoustic Emission after Cyclic Heating and Cooling with Circulating Water. [45]

This paper experimentally studied the damage of granite using acoustic emissions after cyclic heating and cooling with circulating water. They found that the physical and mechanical parameter of granite exhibits exponential relationships with increasing number of cycles. The cumulative number of acoustic emission decreases with the increment of heating and cooling number and the temperature play a key role in the failure mode of samples.

(13) Chen, Y. et al., Coal Anisotropic Sorption and Permeability: An Experimental Study. [46]

This paper presented an experimental study on the anisotropic gas adsorption-desorption and permeability of coal. The results show that an increase in the bedding plane angle of the specimen expands the length and area of the contact surface, thereby increasing the speed and quantity of adsorption and desorption. With an increase in the bedding angle, the number of pores and cracks is found to increase together with the volumetric strain.

(14) Zhang, Q. et al., Effect of Pore Fluid Pressure on the Normal Deformation of a Matched Granite Joint. [47]

Laboratory experiments were carried out to estimate the relationship between pore fluid pressure and normal deformation of joints. They reported that during fluid injection, the joint opens and host rock dilates. The normal deformation of joints can be well described using the proposed exponential functions and the relative normal deformation of host rock during has a linear relationship with the pore fluid pressure. 
(15) Chen, Y. et al., Numerical Simulation on the Dynamic Characteristics of a Tremendous Debris Flow in Sichuan, China. [48]

This paper reported the numerical simulation of Zoumaling debris flow based on computational fluid dynamics (CFD). All these results of the simulations and analyses can guide, and provide suggestions for, the design and construction of prevention engineering for Zoumaling debris flow.

(16) Sha, Z. et al., Experimental Study on the Creep Characteristics of Coal Measures Sandstone under Seepage Action. [49]

This paper investigated the creep characteristics of coal measures sandstone influenced by the effect of seepage. A seepage-creep coupling test system was established and scanning electron microscopy techniques were used. The results show that the maximum creep deformation gradually decreases with the increase in confining pressure. For a fixed confining pressure, the creep deformation, creep deformation rate, and accelerated creep deformation rate, increase dramatically with the increment of infiltration pressure.

(17) Zhou, L. et al., A High-Order Numerical Manifold Method for Darcy Flow in Heterogeneous Porous Media. [50]

The authors adopted a high-order numerical manifold method to improve the simulation accuracy of fluid flow in heterogeneous porous media. They developed a regular mathematical mesh, which is independent of the physical domain and is very efficient and flexible. The proposed new numerical manifold method model is confirmed to be more accurate and efficient, compared with the traditional numerical manifold method model.

(18) Wang, S. et al., Numerical Simulation of Hydraulic Fracture Propagation in Coal Seams with Discontinuous Natural Fracture Networks. [51]

This paper investigated the mechanism of hydraulic fracture propagation in coal seams with discontinuous natural fracture networks by using an innovative cohesive element method. The hydraulic fracture network characteristics, as well as the growth of secondary hydraulic fractures and the pore pressure distribution, were analyzed. The results depict that the hydraulic fracture network is spindle-shaped at a high stress difference condition. The ratio of total length of secondary fracture to that of main fracture is 2.11 3.62, which indicates that the secondary fracture plays a dominate role in coal seams. The process of hydraulic fracture propagation in deep coal seams shows very different behaviors with that in hand and/or tight rocks.

(19) Liu, W. et al., A Coupled Thermal-Hydraulic-Mechanical Nonlinear Model for Fault Water Inrush. [52]

A coupled thermal-nonlinear hydraulic-mechanical (THM) model for fault water inrush was proposed in this paper to study water-rock-temperature interactions and to predict the fault water inrush. The governing equations of the THM coupling model coupled the particle transport equation, the nonlinear flow equation, the mechanical equation and the heat transfer equation. Results show that the water velocity increases with the increasing water pressure. Temperature change in the fault zone is subjected to the interaction of the water pressure and the working face advanced distance. The temperature change in the fault zone can reflect the change in seepage field in the fault and confined aquifer, which can be used to predict the fault water inrush induced by coal mining activities. 
(20) Xu, S. et al., Deformation and Hydraulic Conductivity of Compacted Clay under Waste Differential Settlement. [53]

This paper examined the effect of geogrid reinforcement on the deformation and conductivity of bentonite-sand mixtures subjected to differential settlement. When the hydraulic conductivity is $5 \times 10^{-7} \mathrm{~cm} / \mathrm{s}$, the settlement for a $100 \mathrm{~mm}$ width bentonite-sand mixture with geogrid reinforcement is $100 \mathrm{~mm}$ and increases to $15 \mathrm{~mm}$ for the case without geogrid reinforcement. The obtained results are helpful for predicting the deformation and conductivity of a landfill cover system.

(21) Xue, D. et al., A Strain-Based Percolation Model and Triaxial Tests to Investigate the Evolution of Permeability and Critical Dilatancy Behavior of Coal. [54]

A strain-based percolation model was proposed to model the coupled process of strain and $\mathrm{CH}_{4}$ seepage under triaxial compressions. Using a volume-covering method, it is found that the multiscale fracture network is fractal, which has a linear correlation with the porosity of matrix. The proposed percolation model, which links the axial strain to the permeability, is used to interpret the transitions of volumetric strain and $\mathrm{CH}_{4}$ seepage.

(22) Li, Z. et al., Experimental Study on the Reinforcement Mechanism of Segmented Split Grouting in a Soft Filling Medium. [55]

A series of experiments were carried out to address the reinforcement by segmented split grouting in soft filling media. They establish a quantitative relationship between mechanical behaviors and hydraulic behaviors of soft filling media both before and after grouting. The results exhibit that three types of veins that are skeleton vein, cross-grid grouting vein and parallel dispersed grouting vein are formed with the increase in the distance from the grouting hole. After the skeleton support and compaction, the segmental split grouting shows a significant reinforcement effect on the soft filling media.

(23) Zhang, C. et al., A Numerical Study of Stress Distribution and Fracture Development above a Protective Coal Seam in Longwall Mining. [56]

This paper performed numerical simulations on stress distribution and fracture development above a protective coal seam in longwall mining in Jincheng, China. Five zones are divided for the rock mass above the protective coal seam, including: pre-mining zone, compression zone, expansion zone, recovery zone and re-compacted zone. The boreholes for gas drainage in the coal seam should be drilled in the volume expansion or the dilation zone, in which the gas concentration is high.

(24) Wu, Q. et al., Analysis of Overlying Strata Movement and Disaster-Causing Effects of Coal Mining Face under the Action of Hard Thick Magmatic Rock. [57]

This paper analyzed the overlying strata movement and studied the mechanical behaviors of breaking induced disaster of hard and thick magmatic rocks. The main results are that the magmatic rocks control the development of the bed separation. The distribution of the fracture zone alters with the advance of the working face. The gas and water are accumulated below the bed separation space during the breaking of magmatic rocks and tend to rush towards the working face.

(25) Zhao, C. et al., Shear-Flow Coupled Behavior of Artificial Joints with Sawtooth Asperities. [58]

This paper performed regular shear tests and shear-flow coupled tests on artificial joints that have sawtooth asperities. The influences of joint roughness, normal stress and seepage pressure were systematically analyzed. The results indicate that the shear strength is weakened after a seepage process due to the mutual reinforcing of offsetting and softening effect. The evolution of hydraulic aperture during the tests shows a four-stage characteristic: shear contraction, shear dilation, re-contraction and stability. 
(26) Dou, Z. et al., Temporal Mixing Behavior of Conservative Solute Transport through 2D Self-Affine Fractures. [59]

The authors simulated the temporal mixing behavior of solute transport through self-affine fractures. The influences of Hurst exponent and Peclet number were investigated and the mixing was studied by scalar dissipation rate in fractures. For the parallel plate fracture, the Hurst exponent played a negligible role on the temporal evolution of the scalar dissipation rate when the Peclet number was small. The longitudinal scalar dissipation rate overestimated the global scalar dissipation rate for a large Peclet number.

(27) Yang, X. et al., Numerical Investigation of the Failure Mechanism of Transversely Isotropic Rocks with a Particle Flow Modeling Method. [60]

This paper numerically studied the failure mechanisms of transversely isotropic rocks using a particle flow modeling method. The results show that three modes are observed in the transversely isotropic rock models, including tensile failure across interfaces, shear failure along interfaces, tensile failure along interfaces. The bounded joint cohesion and joint friction angle significantly influence the uniaxial compressive strengths, whereas the joint coefficient of friction and joint tensile strength slightly influence the uniaxial compressive strengths.

Finally, we would like to thank all the authors for their valuable contributions, all the reviewers for their comments that greatly improved the quality of the papers and all the editors from the editorial office for their substantial support for us to handle this Special Issue.

Acknowledgments: This Special Issue on "Fluid flow in fractured porous media" has been partially funded by National Natural Science Foundation of China, China (No. 51709260) and the Fundamental Research Funds of State Key Laboratory for Geomechanics and Deep Underground Engineering, China University of Mining and Technology, China (No. Z18011). These supports are gratefully acknowledged.

Conflicts of Interest: The authors declare no conflict of interest.

\section{References}

1. Juanes, R.; Spiteri, E.; Orr, F.; Blunt, M. Impact of relative permeability hysteresis on geological $\mathrm{CO}_{2}$ storage. Water Resour. Res. 2006, 42. [CrossRef]

2. Juanes, R.; MacMinn, C.; Szulczewski, M. The footprint of the $\mathrm{CO}_{2}$ plume during carbon dioxide storage in saline aquifers: Storage efficiency for capillary trapping at the basin scale. Transp. Porous Media 2010, 82, 19-30. [CrossRef]

3. MacMinn, C.; Szulczewski, M.; Juanes, R. $\mathrm{CO}_{2}$ migration in saline aquifers. Part 1. Capillary trapping under slope and groundwater flow. J. Fluid Mech. 2010, 662, 329-351. [CrossRef]

4. Gerritsen, M.; Durlofsky, L. Modeling fluid flow in oil reservoirs. Annu. Rev. Fluid Mech. 2005, 37, $211-238$. [CrossRef]

5. Haugen, Å.; Fernø, M.; Graue, A.; Bertin, H. Experimental study of foam flow in fractured oil-wet limestone for enhanced oil recovery. SPE Reserv. Eval. Eng. 2012, 15, 218-228.

6. Grant, M.; Donaldson, I.; Bixley, P. Geothermal Reservoir Engineering; Academic Press: New York, NY, USA, 1983.

7. Mora, P.; Wang, Y.; Alonso-Marroquin, F. Lattice solid/Boltzmann microscopic model to simulate solid/fluid systems-A tool to study creation of fluid flow networks for viable deep geothermal energy. J. Earth Sci. 2015, 26, 11-19. [CrossRef]

8. Long, J.; Remer, J.; Wilson, C.; Witherspoon, P. Porous media equivalents for networks of discontinuous fractures. Water Resour. Res. 1982, 18, 645-658. [CrossRef]

9. Wei, W.; Xia, Y. Geometrical, fractal and hydraulic properties of fractured reservoirs: A mini-review. Adv. Geo-Energy Res. 2017, 1, 31-38. [CrossRef]

10. Hartley, L.; Roberts, D. Summary of Discrete Fracture Network Modelling as Applied to Hydrogeology of the Forsmark and Laxemar Sites; Report R-12-04; Swedish Nuclear Fuel and Waste Management Co.: Stockholm, Sweden, 2012. 
11. Neretnieks, I. Channeling effects in flow and transport in fractured rocks-Some recent observations and models. In Proceedings of the GEOVAL-87, International Symposium, Stockholm, Sweden, 14-17 May 1987; pp. 315-335.

12. Dershowitz, W.; Fidelibus, C. Derivation of equivalent pipe network analogues for three-dimensional discrete fracture networks by the boundary element method. Water Resour. Res. 1999, 35, 2685-2691. [CrossRef]

13. Black, J.; Barker, J.; Woodman, N. An Investigation of 'Sparse Channel Networks'-Characteristic Behaviours and Their Causes; Report R-07-35; Swedish Nuclear Fuel and Waste Management Co.: Stockholm, Sweden, 2007.

14. Selroos, J.; Walker, D.; Ström, A.; Gylling, B.; Follin, S. Comparison of alternative modelling approaches for groundwater flow in fractured rock. J. Hydrol. 2002, 257, 174-188. [CrossRef]

15. Figueiredo, B.; Tsang, C.; Niemi, A.; Lindgren, G. Review: The state-of-art of sparse channel models and their applicability to performance assessment of radioactive waste repositories in fractured crystalline formations. Hydrogeol. J. 2016, 24, 1607-1622. [CrossRef]

16. Klimczak, C.; Schultz, R.; Parashar, R.; Reeves, D. Cubic law with aperture-length correlation: Implications for network scale fluid flow. Hydrogeol. J. 2010, 18, 851-862. [CrossRef]

17. Zhao, Z.; Jing, L.; Neretnieks, I. Evaluation of hydrodynamic dispersion parameters in fractured rocks. Journal of Rock Mech. Geotech. Eng. 2010, 2, 243-254. [CrossRef]

18. Cvetkovic, V.; Painter, S.; Outters, N.; Selroos, J. Stochastic simulation of radionuclide migration in discretely fractured rock near the Äspö Hard Rock Laboratory. Water Resour. Res. 2004, 40. [CrossRef]

19. Zhao, Z. Gouge particle evolution in a rock fracture undergoing shear: A microscopic DEM study. Rock Mech. Rock Eng. 2013, 46, 1461-1479. [CrossRef]

20. Min, K.; Rutqvist, J.; Tsang, C.; Jing, L. Stress-dependent permeability of fractured rock masses: A numerical study. Int. J. Rock Mech. Min. Sci. 2004, 41, 1191-1210. [CrossRef]

21. Parashar, R.; Reeves, D. On iterative techniques for computing flow in large two-dimensional discrete fracture networks. J. Comput. Appl. Math. 2012, 236, 4712-4724. [CrossRef]

22. Latham, J.; Xiang, J.; Belayneh, M.; Nick, H.; Tsang, C.; Blunt, M. Modelling stress-dependent permeability in fractured rock including effects of propagating and bending fractures. Int. J. Rock Mech. Min. Sci. 2013, 57, 100-112. [CrossRef]

23. Huang, N.; Jiang, Y.; Li, B.; Liu, R. A numerical method for simulating fluid flow through 3-D fracture networks. J. Nat. Gas Sci. Eng. 2016, 33, 1271-1281. [CrossRef]

24. Zimmerman, R.; Al-Yaarubi, A.; Pain, C.; Grattoni, C. Non-linear regimes of fluid flow in rock fractures. Int. J. Rock Mech. Min. Sci. 2004, 41, 163-169. [CrossRef]

25. Zhang, Z.; Nemcik, J. Fluid flow regimes and nonlinear flow characteristics in deformable rock fractures. J. Hydrol. 2013, 477, 139-151. [CrossRef]

26. Javadi, M.; Sharifzadeh, M.; Shahriar, K.; Mitani, Y. Critical Reynolds number for nonlinear flow through rough-walled fractures: The role of shear processes. Water Resour. Res. 2014, 50, 1789-1804. [CrossRef]

27. Chen, Y.; Hu, S.; Hu, R.; Zhou, C. Estimating hydraulic conductivity of fractured rocks from high-pressure packer tests with an Izbash's law-based empirical model. Water Resour. Res. 2015, 51, 2096-2118. [CrossRef]

28. Zhou, J.; Hu, S.; Fang, S.; Chen, Y.; Zhou, C. Nonlinear flow behavior at low Reynolds numbers through rough-walled fractures subjected to normal compressive loading. Int. J. Rock Mech. Min. Sci. 2015, 80, 202-218. [CrossRef]

29. Zhou, J.; Wang, M.; Wang, L.; Chen, Y.; Zhou, C. Emergence of nonlinear laminar flow in fractures during shear. Rock Mech. Rock Eng. 2018. [CrossRef]

30. Rong, G.; Yang, J.; Cheng, L.; Zhou, C. Laboratory investigation of nonlinear flow characteristics in rough fractures during shear process. J. Hydrol. 2016, 541, 1385-1394. [CrossRef]

31. Zou, L.; Jing, L.; Cvetkovic, V. Shear-enhanced nonlinear flow in rough-walled rock fractures. Int. J. Rock Mech. Min. Sci. 2017, 97, 33-45. [CrossRef]

32. Yin, Q.; Ma, G.; Jing, H.; Wang, H.; Su, H.; Wang, Y.; Liu, R. Hydraulic properties of 3D rough-walled fractures during shearing: An experimental study. J. Hydrol. 2018, 555, 169-184. [CrossRef]

33. Yin, Q.; Jing, H.; Ma, G.; Su, H.; Liu, R. Investigating the roles of included angle and loading condition on the critical hydraulic gradient of real rock fracture networks. Rock Mech. Rock Eng. 2018. [CrossRef]

34. He, L.; Yin, Q.; Jing, H. Laboratory Investigation of Granite Permeability after High-Temperature Exposure. Processes 2018, 6, 36. [CrossRef] 
35. Jin, Y.; Han, L.; Meng, Q.; Ma, D.; Han, G.; Gao, F.; Wang, S. Experimental Investigation of the Mechanical Behaviors of Grouted Sand with UF-OA Grouts. Processes 2018, 6, 37. [CrossRef]

36. Yan, S.; Liu, T.; Bai, J.; Wu, W. Key Parameters of Gob-Side Entry Retaining in a Gassy and Thin Coal Seam with Hard Roof. Processes 2018, 6, 51. [CrossRef]

37. Li, J.; Huang, Y.; Qiao, M.; Chen, Z.; Song, T.; Kong, G.; Gao, H.; Guo, L. Effects of Water Soaked Height on the Deformation and Crushing Characteristics of Loose Gangue Backfill Material in Solid Backfill Coal Mining. Processes 2018, 6, 64. [CrossRef]

38. Liu, J.; Wan, Z.; Xie, Q.; Li, C.; Liu, R.; Cheng, M.; Han, B. Investigation on Reinforcement and Lapping Effect of Fracture Grouting in Yellow River Embankment. Processes 2018, 6, 75. [CrossRef]

39. Ma, C.; Wang, P.; Jiang, L.; Wang, C. Deformation and Control Countermeasure of Surrounding Rocks for Water-Dripping Roadway below a Contiguous Seam Goaf. Processes 2018, 6, 77. [CrossRef]

40. Liu, R.; Liu, H.; Sha, F.; Yang, H.; Zhang, Q.; Shi, S.; Zheng, Z. Investigation of the Porosity Distribution, Permeability, and Mechanical Performance of Pervious Concretes. Processes 2018, 6, 78. [CrossRef]

41. Xie, X.; Liu, J.; Han, B.; Li, H.; Li, Y.; Li, X. Critical Hydraulic Gradient of Internal Erosion at the Soil-Structure Interface. Processes 2018, 6, 92. [CrossRef]

42. Cui, Y.; Lu, B.; Wu, M.; Luo, W. A New Pseudo Steady-State Constant for a Vertical Well with Finite-Conductivity Fracture. Processes 2018, 6, 93. [CrossRef]

43. Li, Z.; Li, L.; Zhang, Z.; Li, M.; Zhang, L.; Huang, B.; Tang, C. The Fracturing Behavior of Tight Glutenites Subjected to Hydraulic Pressure. Processes 2018, 6, 96. [CrossRef]

44. Chen, S.; Zhang, D.; Shang, T.; Meng, T. Experimental Study of the Microstructural Evolution of Glauberite and Its Weakening Mechanism under the Effect of Thermal-Hydrological-Chemical Coupling. Processes 2018, 6, 99. [CrossRef]

45. Zhu, D.; Jing, H.; Yin, Q.; Han, G. Experimental Study on the Damage of Granite by Acoustic Emission after Cyclic Heating and Cooling with Circulating Water. Processes 2018, 6, 101. [CrossRef]

46. Chen, Y.; Li, X.; Li, B. Coal Anisotropic Sorption and Permeability: An Experimental Study. Processes 2018, 6, 104. [CrossRef]

47. Zhang, Q.; Li, X.; Bai, B.; Hu, S.; Shi, L. Effect of Pore Fluid Pressure on the Normal Deformation of a Matched Granite Joint. Processes 2018, 6, 107. [CrossRef]

48. Chen, Y.; Qiu, Z.; Li, B.; Yang, Z. Numerical Simulation on the Dynamic Characteristics of a Tremendous Debris Flow in Sichuan, China. Processes 2018, 6, 109. [CrossRef]

49. Sha, Z.; Pu, H.; Li, M.; Cao, L.; Liu, D.; Ni, H.; Lu, J. Experimental Study on the Creep Characteristics of Coal Measures Sandstone under Seepage Action. Processes 2018, 6, 110. [CrossRef]

50. Zhou, L.; Wang, Y.; Feng, D. A High-Order Numerical Manifold Method for Darcy Flow in Heterogeneous Porous Media. Processes 2018, 6, 111. [CrossRef]

51. Wang, S.; Li, H.; Li, D. Numerical Simulation of Hydraulic Fracture Propagation in Coal Seams with Discontinuous Natural Fracture Networks. Processes 2018, 6, 113. [CrossRef]

52. Liu, W.; Zhao, J.; Nie, R.; Liu, Y.; Du, Y. A Coupled Thermal-Hydraulic-Mechanical Nonlinear Model for Fault Water Inrush. Processes 2018, 6, 120. [CrossRef]

53. Xu, S.; Li, C.; Liu, J.; Bian, M.; Wei, W.; Zhang, H.; Wang, Z. Deformation and Hydraulic Conductivity of Compacted Clay under Waste Differential Settlement. Processes 2018, 6, 123. [CrossRef]

54. Xue, D.; Zhou, J.; Liu, Y.; Zhang, S. A Strain-Based Percolation Model and Triaxial Tests to Investigate the Evolution of Permeability and Critical Dilatancy Behavior of Coal. Processes 2018, 6, 127. [CrossRef]

55. Li, Z.; Li, S.; Liu, H.; Zhang, Q.; Liu, Y. Experimental Study on the Reinforcement Mechanism of Segmented Split Grouting in a Soft Filling Medium. Processes 2018, 6, 131. [CrossRef]

56. Zhang, C.; Yu, L.; Feng, R.; Zhang, Y.; Zhang, G. A Numerical Study of Stress Distribution and Fracture Development above a Protective Coal Seam in Longwall Mining. Processes 2018, 6, 146. [CrossRef]

57. Wu, Q.; Wu, Q.; Xue, Y.; Kong, P.; Gong, B. Analysis of Overlying Strata Movement and Disaster-Causing Effects of Coal Mining Face under the Action of Hard Thick Magmatic Rock. Processes 2018, 6, 150. [CrossRef]

58. Zhao, C.; Zhang, R.; Zhang, Q.; Shi, Z.; Yu, S. Shear-Flow Coupled Behavior of Artificial Joints with Sawtooth Asperities. Processes 2018, 6, 152. [CrossRef] 
59. Dou, Z.; Sleep, B.; Mondal, P.; Guo, Q.; Wang, J.; Zhou, Z. Temporal Mixing Behavior of Conservative Solute Transport through 2D Self-Affine Fractures. Processes 2018, 6, 158. [CrossRef]

60. Yang, X.; Jing, H.; Qiao, W. Numerical Investigation of the Failure Mechanism of Transversely Isotropic Rocks with a Particle Flow Modeling Method. Processes 2018, 6, 171. [CrossRef]

(C) 2018 by the authors. Licensee MDPI, Basel, Switzerland. This article is an open access article distributed under the terms and conditions of the Creative Commons Attribution (CC BY) license (http://creativecommons.org/licenses/by/4.0/). 